\title{
REVISITING THE GREED AND GRIEVANCE EXPLANATIONS FOR VIOLENT INTERNAL CONFLICT ${ }^{*}$
}

\author{
Syed Mansoob Murshed \\ The Birmingham Business School \\ University of Birmingham \\ Edgbaston, Birmingham B15 2TT, UK. \\ Institute of Social Studies (ISS) \\ PO Box 29776 \\ 2502 LT, The Hague, The Netherlands \\ Centre for the Study of Civil War (CSCW) \\ PRIO, Oslo, Norway \\ Murshed@iss.nl \\ \& \\ Mohammad Zulfan Tadjoeddin \\ University of Western Sydney, Australia \\ Institute of Social Studies (ISS) \\ z.tadjoeddin@uws.edu.au
}

\begin{abstract}
Two phenomena have been recently utilised to explain conflict onset among rational choice analysts: greed and grievance. The former reflects elite competition over valuable natural resource rents. The latter argues that relative deprivation and the grievance it produces fuels conflict. Central to grievance are concepts of inter-ethnic or horizontal inequality. Identity formation is also crucial to intra-state conflict, as it overcomes the collective action problem. Conflict can rarely be explained by greed alone, yet, the greed versus grievance hypotheses may be complementary explanations for conflict. The greed explanation for conflict duration and secessionist wars works best in cross-country studies, but has to make way for grievance-based arguments in quantitative country-case studies. Grievances and horizontal inequalities may be better at explaining why conflicts begin, but not necessarily why they persist. Neither the presence of greed or grievance is sufficient for the outbreak of violent conflict, something which requires institutional breakdown, which we describe as the failure of the social contract. The degradation of the social contract is more likely in the context of poverty and growth failure. We provide a synthesis of the greed and grievance hypotheses, including comments on post-conflict reconstruction.
\end{abstract}

Keywords: Conflict, civil war, greed versus grievance, social contract, post-conflict reconstruction

J.E.L Codes: D72, D74, O10, O40.

\footnotetext{
* This paper is written as part of the European Union (EU) funded, MICROCON research project on conflict. We are grateful to the EU for financial assistance.
} 
Civil war is a multi-faceted problem. Not only does it produce human tragedies on a colossal scale, but it creates humanitarian crises that are of concern to the international community, as well as contributing to global and regional insecurity. Civil war is also a major cause of underdevelopment, and perpetuates poverty, see Murshed (2002) and Collier et. al. (2003). The number of countries embroiled in a civil war increased up to 1994, and has since declined (Hegre, 2004). See Harbom, Högbladh and Wallensteen (2006) for an enumeration of the number of armed conflicts in the post-second world war period. The number of new civil wars emerging also seems to have fallen in the last decade (Hegre, 2004). But the average duration of civil wars, standing at 16 years in 1999, does not exhibit a downward trend (Fearon, 2004). For all of these reasons ending conflict or reducing its intensity must be a very high policy imperative in the development agenda.

Civil wars are not a homogenous phenomenon. Their origins, motivations and objectives vary. A useful guide to the typology of conflict can be found in Besançon (2005). The discussion on the typology of civil war points to four broad types: genocides, revolutions or rebellions against the state, secessionist wars and internationalised wars (where adjoining states or the great powers get involved). Many examples of contemporary conflict do not always fit neatly into only one of the categories mentioned. Besides civil wars, there are other forms of large scale organised violence. Transnational terrorism is the most important 'other' type of collective violence, where the perpetrators have a very different motivation compared to participants of civil wars. In addition, we also have routine and sectarian violence where the state is not a direct protagonist (hence they are not civil wars).

According to the rational choice paradigm, conflict is a result of choice. This may be of a myopic nature, as negotiated settlements which avoid the losses that ensue from war, are usually Pareto superior. Another way of stating this is that conflict is a special form of non-cooperative behaviour; other forms of non-cooperative behaviour which are less destructive, and cooperation are superior to costly non-cooperative interaction. But circumstances (constraints, poverty, institutional failure), mistrust (coordination failure), impatience and myopia (discounting the future) may rule out cooperation or more peaceful forms of non-cooperative negotiation, making conflict an optimal choice for group leaders who have to take into account, at least, some of the interests of their followers.

In recent years, two phenomena have been utilised to explain conflict onset among academic economists: greed and grievance. The former is due to the influential work of Paul Collier (see, Collier and Hoeffler, 2002, 2004), and is more popular amongst economists. According to this view, conflict reflects elite competition over valuable natural resource rents, concealed with the fig leaf of collective grievance. Additionally, rebellions need to be financially viable: civil wars supported by natural resource based rents like blood diamonds or oil, or when sympathetic diasporas provide a ready source of finance, are more likely to occur. Above all, there was the assertion that 
inequality played no part in adding to the risk of civil war. More recently, Paul Collier and his associates (2003) emphasise the poverty trap: poverty makes soldiering less unattractive, more generally lowering the opportunity cost of war in poor nations. In turn, conflict serves to perpetuate poverty because of war's destructiveness; a vicious cycle of poverty-conflict-poverty ensues. Collier's views are extremely influential in donor policy circles (including ministers in charge of disbursing aid), and has received immense publicity in the Western media (Financial Times, International Herald Tribune, Time). Fearon and Laitin (2003) assert that ethnic or religious diversity makes little contribution to civil war risk, which are mainly caused by diminished state capacity in the context of poverty. This finding, taken together with Collier's work has a simple intuitive appeal; civil wars occur in poverty stricken, failed states characterised by venal, corrupt and inept regimes, with the dynamics of war sustained by a motivation akin to banditry. It also provides intellectual excuses for direct, colonial style, intervention to prevent failing states from collapsing.

But in many ways, these views go against the grain. There is a long-standing position in political science that relative deprivation (Gurr, 1970) and the grievance that it produces fuels internal violence. Identity is also crucial to intra-state conflict. This is due to the collective action problem, as discussed in Olson (1965). It is difficult to mobilise large groups to undertake collective action, because of mutual mistrust, monitoring difficulties and the free-rider problem. Ethnic identities, whether based on race, language, religion, tribal affiliation or regional differences, may serve as a more effective amalgam for the purposes of group formation, compared to other forms of more transient difference that are traditionally stressed by Marxist writers, such as socioeconomic class. The formation of enduring identities are therefore central to mobilising groups, including the machinations of conflict entrepreneurs who organise men to fight each other; see Tilly (1978) and Gurr (2000) on this. Conflict cannot proceed without the presence of palpably perceived group differences, or grievance, which may have historical dimensions. More recently, Frances Stewart (2000) has introduced the notion of horizontal inequality, the inequality between groups, rather than the inequality that may exist amongst an ethnically homogenous population (vertical inequality). Indeed, it may be the case that vertical inequality in a homogenous population, despite the class differences it engenders, does not seriously increase the risk of conflict (Collier and Hoeffler, 2004). But that could still leave a role for group inequality (for which data is scarce), which these authors choose to ignore.

The purpose of this paper is to critically review the greed versus grievance hypotheses. The rest of the work is organised as follows. Section 2 examines the greed hypothesis, whereas section 3 looks at issues relating to grievance and horizontal inequality. Section 4 puts forward a synthesis of greed and grievance related to malfunctioning institutions, which may be described as the social contract. Finally, section 5 concludes with a summary. 


\section{The Greed or Natural Resource Based Explanation for Conflict}

This section shall proceed as follows. We start with a discussion on the theory of greed for conflict; we then examine measurement issues and their implications for the cross country empirical evidence on greed.

\subsection{The theory of greed}

The greed motivation behind civil war has been popularised by empirical work $^{1}$ on the causes of civil war where a cross-section of conflicts in different nations is analyzed together econometrically, and greed is proxied by the availability or abundance of capturable natural resource rents. In Collier and Hoeffler (2004) civil wars stem from the greedy behaviour of a rebel group in organising an insurgency against the government. Greed is about opportunities faced by the rebel group. The opportunities can be disaggregated into there components: financing, recruitment and geography. The most common sources of rebel finance are the appropriation of natural resources, donations from sympathetic diasporas residing abroad, contributions from foreign states (hostile to the government) or multinational companies interested in the region. Natural resource wealth is the chief among the three in terms of its relative importance. Recruitment is about the opportunity to induct fighting manpower; something made easier when there is a high proportion of young unemployed males in population, in a setting of endemic poverty and poor education. Geographical situations favourable to rebel group are mountainous terrain and other safe havens for insurgents. In short, greed simply means the 'economic opportunity' to fight, and should be distinguished from socio-political grievances. Collier and Hoeffler's (2004) empirical findings conclude that the set of variables representing rebel opportunity or greed akin to loot-seeking are the main reasons for civil war. By implication, the alternative hypothesis of grievance (justice-seeking) focusing on ethnic religious divisions, political repression and horizontal inequality is dismissed, although its invalidity is not formally tested for. Natural resource rents constitute 'booty' and this fact has been used to emphasise the greed or criminal motivation for civil war. Central to the Collier and Hoeffler's empirical testing for the greed hypothesis is the role of primary commodities in the economic structure. They measure the dependence on natural resources by the share of primary commodity exports in GDP, and the validity of this metric as well as the statistical robustness of the relationship between resource rents and the risk of conflict has been called into question. Be that as it may, the combined Collier and Hoeffler greed and Fearon and Laitin (2003) messages about greed and state failure causing rebellion or civil war has had an immense influence in the media and the donor policy community's thinking about conflict.

The econometric models purporting to establish the empirical validity of the greed hypothesis, however, are atheoretical, in the sense of not having a formal economic model based on optimising behaviour by economic agents to explain why greed may cause conflict. If economic agents (homo economicus)

\footnotetext{
${ }^{1}$ Mainly, although not exclusively, by Paul Collier and associates.
} 
are actuated only by self-interest ${ }^{2}$, we must demonstrate why they choose war over other alternatives. Therefore, any theorising about greed must be based on the economic motivations for violence and criminality. Belligerents in the wars of natural-resource rich countries could be acting in ways close to what Olson (1996) referred to as 'roving bandits' —who have no encompassing interest in preserving the state or its people but are simply intent on loot-than to 'stationary' bandits who take control of the state and seek to maximise their own profit by encouraging stability and growth in their new domain. Civil wars motivated by the desire to control natural resource rents could also mirror "warlord competition", a term that owes its origins to the violent competition between leaders attempting to control economic resources in the context of medieval Europe, Skaperdas (2002).

In a nutshell, a proper greed-based theory of civil war must relate to the tradeoff between production and predation in making a living, where we may view war as theft writ large. Violence is one means of appropriating the resources of others. Note, that armed conflict implies the absence of contractual interaction (Edgeworth, 1881), and is in stark contrast to the alternative method of benefiting from the endowments of others via peaceful and voluntary exchange (trade) between economic agents, groups or nations. This implies that we also need to specify the conditions under which violence becomes a viable or more attractive option relative to other alternatives.

A variety of game theoretic models describing the non-cooperative and conflictive interaction between groups exist, where the object is to capture the rival's endowment by force. One such model is due to Hirshleifer (1995), where each group has a fixed resource endowment, which can be used to either produce goods for consumption or armaments to fight the other group. Groups exist in a state of non-contractual anarchy vis-à-vis each other; this also implies the absence of enforceable property rights. The object of fighting is to capture some of the rival's endowment. Success in war is uncertain, and the probability of victory is given by a Tullock (1980) contest success function, where the probability of victory for any group is given by their own military expenditure relative to the total fighting outlay made by all protagonists. Additionally, there is a military effectiveness parameter (akin to what is known as a force multiplier in military establishments); something that raises the effectiveness of each unit of fighting effort. In the absence of increasing returns to scale in military effectiveness, and if a minimum subsistence income is present there will be a Nash non-cooperative equilibrium associated with some fighting. In other words, in the equilibrium both (or all) parties will be engaged in some fighting with each other, as well as some productive activities; unless one side manages to conquer others due to its individual military superiority. Hirshleifer (1995) describes this as a state of anarchy -something akin to primitive tribal warfare. Note, no possibility of trade is permitted between groups.

Skaperdas (1992) outlines a model that is similar because it has a fixed resource endowment which can be devoted to either production or armament.

\footnotetext{
${ }^{2}$ This commonly held view is actually a gross over-simplification.
} 
The probability of success in war also depends on a similar contest success function. Skaperdas (1992), however, allows for a peaceful trading cooperative equilibrium when there is no fighting. The parties simply share the sum of total resources in proportion to the contest success function, or in accordance with what would have been the equilibrium outcome of war. This is likely when the probability of military success for either side is low, and both parties are similar in their peaceful productive capacities. Secondly, there is a possible outcome where one side only produces, whereas the other party does some fighting and production. This is a more likely outcome when the more pacific side is more productive, and the side that chooses fighting is more efficient at it. Finally, both sides may choose a mix of fighting and production. As with the first possibility, each side must be similar in their economic productivity and fighting effectiveness, but here the technology of war is such that it raises the probability of victory for both sides, hence the presence of fighting. In many ways, Skapedas's (1992) model puts the tradeoff between fighting and predation into sharper perspective, and explicitly mentions the absence of contract or respect for property rights. ${ }^{3}$

Both these models, however, neglect the destructiveness of war (collateral damage), and its capacity to ravage productive capacity, additional to direct military expenditure. These models employ intermediate inputs, and not factors of production, which can be costlessly shifted between fighting and production. Secondly, there is no growth in these models, something which would raise the opportunity costs of war. A similar effect could arise from complementarities in production between groups and/or economies of scale, which would make mergers between groups or cooperation in each group's self-interest. Thirdly, the possibilities of peaceful exchange need to be limited (absent in Hirshleifer, 1995) in order to rationalise conflict. In traditional economics the gains from trade arise mainly from differences in tastes, technology and endowments, and these gains from trade need to be minimised in order to make conflict an optimal choice. Violent means are attractive when the intention is to extract resources (as in the case of colonial plantations and mines) or accumulate surpluses at the expense of others (mercantilism). Fourthly, these models imply full information. In the presence of asymmetric information, misperceptions about contest success, the opposition's intentions and so on, wars that do not maximise expected utility under full information may break out, akin to problems associated with moral hazard and adverse selection. Fifthly, such theorising is broadly blind to institutions (despite ruling out the existence of property rights and betweengroup contracts), and the presence of transactions costs that breed mutual mistrust. Wars can also reflect the absence of institutions which facilitate negotiation and peaceful exchange.

Despite these limitations, there is much in these models that can explain the greedy behaviour as analyzed by the empirical exponents of the greed hypothesis. The presence of readily capturable natural resource based rents may make conflict more attractive when compared to peaceful production, as

\footnotetext{
${ }^{3}$ Even in societies with property rights, there still may be violent or non-violent competition over resources which have, as yet, unassigned ownership.
} 
can a shortage of intermediate inputs due to population pressure. These resources are best regarded as a non-produced 'prize' such as oil or diamonds (which apart from extraction costs are like manna from heaven), whose ownership is violently contested. Secondly, contributions from a sympathetic diaspora (or aid from a super-power in the cold war era) can raise the probability of victory of a potential rebel group against the state. Thirdly, the inability of the state to act as a Stackelberg leader in a potentially divided nation may raise the chances of war between groups in a manner similar to the weak state capacity mechanism favoured by some political scientists (like James Fearon). For example, in the Hirshleifer (1995) model where different groups are in a state of anarchy vis-à-vis one another, the ability of one group to behave as a Stackelberg leader reduces equilibrium fighting levels and raises each side's per-capita income. The leader, however, gains relatively less compared to followers, creating an incentive for each side to be a follower. If one group is strong and militarily more effective it will dominate other groups, and there will be no fighting in the equilibrium. This may lead to state formation, which may or may not lead to the re-configuration of group identities. If inter-group rivalries persist, state disintegration occurs when the dominant group can no longer control other groups.

Finally, war implies the absence of contract, and warring parties may enter into contracts that make their interactions more peaceful. This will be all the more true, if war causes substantial collateral damage. Groups may also decide to merge in order to reap economies of scale in production. If they do not do so when it is clearly in their mutual self-interest we have to resort to explanations based on misperceptions, mistrust or the lack of institutions that enforce contracts. Alternatively, the institutions that once bound groups together may have disintegrated. We shall return to these issues in section 4. We now return to the empirical hypotheses that buttress cross-country econometric studies of civil war, which are dominated by various forms of a greed (or modified greed) and state failure hypotheses.

\subsection{Empirical Issues in Connection with the Greed Mechanism}

While Collier and Hoeffler $(2002,2004)$ push for the case of the greedy rebel mechanism derived from their findings regarding the strong explanatory power of the share of primary commodity export to GDP (as a proxy for natural resource wealth), others are less sanguine. In short, the empirical controversy over the link between natural resource wealth and greed hypothesis are about the saliency of mechanisms in-between natural resource rents and conflict, as well as measurement issues and estimation techniques.

Humphreys (2005), for example, argues that other mechanisms may be present. First, is the greedy outsider mechanism: the existence of natural resources may be an incentive for third parties-states and corporations - to engage in or indeed foster civil conflict. Second, is the grievance mechanism: natural resource dependence could in fact be associated with grievances rather than greed. There are at least four variants of this mechanism: (i) countries with middling levels of dependence on natural resources may be experiencing transitory inequality as part of the development process, (ii) 
economies that are dependent on natural resources may be more vulnerable to terms of trade shocks, (iii) the process of extraction may produce grievances, for example, through forced migration, and (iv) natural resources wealth may be seen as more unjustly distributed than other wealth. Third, is the weak state mechanism. Natural resource dependent economies may have weaker states, which stems from the nature of state revenue that is dependent on resource rents. On the one hand, untaxed citizens have less ability or incentive to monitor state activity. On the other hand, governments relying more on natural resource rents rather than taxation have weak incentives to create strong and accountable bureaucratic structures, similar to the logic of no accountability without taxation (Ross, 2004a).

Any measure of natural resource dependence may also be endogenous to conflict, which has two implications: (i) reverse causality, in which civil wars might cause resource dependence by reducing the size of a country's nonresource sector (e.g. manufacturing), and (ii) spurious correlation, where both civil war and resource dependence might be independently caused by an unmeasured third variable, such as poor property rights or the weak rule of law.

On the matter of measurement, two broad sets of issues need to be considered: (i) the measure of natural resource wealth/dependence, and (ii) the construction of the relevant conflict dependent variable.

Before we examine the various alternative metrics for natural resource dependence, note that the term primary commodity includes both agricultural commodities and minerals/fuels, but crucially excludes illegal substances (coca and heroin) as well as illegal alluvial diamonds in Collier and Hoeffler (2002, 2004). Certain varieties of resources are more easily captured: they may be lootable such as alluvial diamonds (in Sierra Leone, Angola) available along river beds using artisanal techniques or illicit drugs such as coca in Colombia; obstructable like an oil pipe line; see Ross (2003) on these issues. Illicit gemstones and drugs are arguably more crucial to financing rogue conflict entrepreneurs in a greed based conflict; their omission is a serious flaw. Collier and Hoeffler $(2002,2004)$ do not differentiate different types of natural resources, such as between lootable and non-lootable natural resources (Lujala, Gleditsch and Gilmore 2005), and between point-source and diffuse natural resources (Murshed, 2004). Lootable point source natural resources are in particular prone to be illegally exploited and traded. Collier and Hoeffler $(2002,2004)$ are only concerned with past natural production, neglecting future prospects for extraction (Humphreys, 2005). They also only focus on exports, even though production might be a better measure of the availability of these resources, including commodities that were first imported and then re-exported (Humphreys, 2005).

Below is a summary of different proxies to measure resource wealth used in cross country empirical conflict literature:

- Primary commodity exports as percentage of GDP (Collier and Hoeffler, 2002, 2004).

- Agricultural value added as percentage of GDP (Humphreys, 2005). 
- Oil dependence; different ways of measuring this have been employed:

o Oil production and reserves per capita (Humphreys, 2005). This is to distinguish between past and future exploitation of natural resources.

o Oil rents per capita, that is further distinguished between off-shore and on-shore oil (Ross, 2006).

o Oil exporter dummy, where oil exceeds one-third of total exports (Fearon and Laitin, 2003).

o Oil exports as percentage of total exports; Fearon (2005) adds this measure to the Collier-Hoeffler model to specifically locate the oil effect, finding that the effect of primary commodities on conflict is confined to oil.

- Diamonds; different ways of measuring diamond wealth have been employed:

o Diamond production per capita (Humphreys, 2005). Ross (2006) further disaggregates it into primary and secondary production to differentiate the unlootable and lootable nature of this resource.

o A dummy for the presence of diamonds and disaggregated further into primary and secondary (Lujala, Gleditsch and Gilmore 2005). They find that the lootable secondary diamonds increases the risk of civil war onset and its duration, while the primary one does not. They create mainly ethnic civil wars rather than other forms of civil wars. This risk has been greater since the end of the cold war. Non-lootable deep mine shaft diamonds, however, lowers the risk of civil war onset.

- Resource rents as percentage of gross national income (de Soysa and Neumayer, 2007). They differentiate between energy rents and mineral rents; the former consists of oil, gas and coal, while the latter includes bauxite, copper, iron ore, lead, nickel, phosphate rock, tin, zinc, gold and silver.

- Contraband dummy; conflicts in which a rebel group derives major funds from contraband such as opium, diamonds, or coca tend to have longer civil war duration (Fearon, 2004).

Another related issue is the proper specification of the conflict dependent variable in econometric analyses; it can either be the onset or duration of civil war. With regard to onset, the question is whether natural resource wealth increases or decreases the risk or likelihood of civil war; and with duration, whether or not it prolongs civil war. Collier and Hoeffler $(2002,2004)$ claim that resource abundance measured by primary goods exports to GDP in increasing the likelihood of civil war onset is significant and robust; while others say that it is not significant (Fearon and Laitin, 2003; Fearon, 2005) or it is not robust (Ross, 2004b). On duration, the results are again contradictory. Collier, Hoeffler and Soderbom (2004) find that primary commodities have no significant effect on the duration; but decreases in primary commodity prices would shorten conflict since it squeezes rebel finances, when the level of dependence upon primary commodity exports is high. Using contraband dummy measures, Fearon (2004) and Ross (2006) find that natural resources 
lengthen civil war duration; while using diamond production per capita, Humphreys (2005) finds that this reduces war duration.

When civil war onset is a dummy $(0,1)$ variable, an additional complication is regarding the appropriate fatality threshold for coding a case as a civil war/conflict. There are three variants employed: (i) 1000 battle related deaths annually (Collier and Hoeffler, 2004), (ii) 1000 battle related deaths during the course of the conflict (Fearon and Laitin, 2003; Fearon, 2005), and (iii) 25 battle related deaths annually (de Soysa, 2002).

On estimation techniques, Fearon (2005) provides the strongest challenge to Collier and Hoeffler's (2002, 2004) empirical finding on the link between primary commodity exports and civil war. Fearon, who re-estimates Collier and Hoeffler's model using country-year observations, as apposed to countryfive year observations employed by Collier and Hoeffler, ${ }^{4}$ finds that the significance of statistical associations between primary commodity export and civil war onset vanish in the country-year regression, meaning that the previous claim of such a relationship is simply not robust. In other words, this cross-country result will not withstand variation in sample and data coverage. A similar view is shared by Ross (2004b), who reviews 14 cross country empirical studies on natural resource and civil war. Ross (2004b) concludes that the claim that primary commodities are associated with the onset of civil war does not appear to be robust, oil dependence appears to be linked to the initiation of conflict, but not its duration, and illicit gemstones and drugs seem to lengthen pre-existing wars. Furthermore, Fearon (2005) shows that the effect of primary commodity exports is confined to oil; this is by adding the variable (oil exports to total exports) into the country-year regression. Humphreys (2005) checks the effect of past oil exploitation (oil production per capita) on civil war onset and finds it positively significant. However, he asserts that such a relationship works through the weak state mechanism; this is by adding interaction terms between measures of natural resource wealth and state weaknesses. In a similar vein to Humphreys, Fearon (2005) interprets the oil effect as a weak state mechanism rather than a greedy rebel hypothesis; this is by using the correlation between oil export and state weaknesses -measured by government observance of contracts.

Reverting back to the Collier and Hoeffler greed hypothesis, properly stated it is actually an interpretation of their empirical finding that natural resource abundance increases the risk of civil war. As Collier and Hoeffler (2004: 588) conclude, 'we have interpreted this as being due to the opportunities such as commodities provide for extortion, making rebellion feasible, and perhaps even attractive'. This lies at the heart of their famous greedy rebel mechanism. However, there is really no empirical evidence showing the validity of such an interpretation. In this respect, Fearon (2005) and Humphreys (2005) go one step further by providing empirical evidence of their

\footnotetext{
${ }^{4}$ The method of multiple imputations do not lead to Collier and Hoeffler's (2004) list-wide deletion, because in the latter case arbitrary five year averages result in twenty seven out of the seventy nine conflict cases being dropped due to missing data on right-hand side explanatory variables. However, it should be noted that Fearon (2005) used a lower threshold for civil war related death compared with Collier and Hoeffler (2004).
} 
weak state mechanism as the intervening mechanism between natural resource endowments and civil war, as opposed to the greedy rebel mechanism. De Soysa and Neumayer (2007) support such an argument. Using resource rents data as the percentage of national income (differentiated into energy and mineral rents), they re-estimate both Collier and Hoeffler (2004) and Fearon and Laitin (2003) models using different thresholds for civil war. They find that only energy rents matter for civil war onset, and reject the curvilinear relationship between resource dependence and civil war as proposed by Collier and Hoeffler. De Soysa and Neumayer interpret that the significant role of energy rents is more relevant with the weak state mechanism rather than the greedy rebel-hypothesis.

Facing these challenge, Collier, Hoeffler and Rohner $(2007)^{5}$ revisit their previous greed argument by saying that, 'the feasibility hypothesis proposes that where rebellion is feasible it will occur: motivation is indeterminate, being supplied by whatever agenda happens to be adopted by the first social entrepreneur to occupy the viable niche' (p. 21). They differentiate between two theories of civil war: 'feasibility' and 'motivation' which in turn has two variants, i.e. either 'greed' or 'grievance'. But, the content of their previous 'greed' hypothesis (now part of motivation) is almost identical with what they now re-phrase as 'feasibility'. If feasibility is about opportunity, greed is also about opportunity. The basic arguments and empirical evidence are much the same as before.

A recent paper by Brunnschweiler and Bulte (2008), clearly differentiates between resource dependence and abundance. The share of primary commodity exports to GDP is their resource dependence measure. For resource abundance, they use the aggregate measure of the net present value of rents (in US\$ per capita) of a country's total natural capital stock, and by considering two disaggregated measures: focusing on sub-soil mineral resources and land (crop and pastureland, protected areas and forest resources). They treat resource dependence as endogenous independent variables in their conflict regressions. By using a set of instruments for resource dependence, as well as income, which consist of a measure of resource abundance, trade openness, the constitution (presidential versus parliamentarian systems), absolute latitude, percentage of land in the tropics and distance from the nearest coast or navigable river, they find that by treating these two variables as endogenous, resource dependence loses its significance and resource abundance has a negative indirect effect on conflict through income. Thus, the previous arguments for placing natural resource wealth or dependence as the principal culprit for civil war are invalidated.

In summary, greed based explanations for conflict require further refinement by utilising better data on capturable resource rents. Proper consideration also needs to be given to institutional mechanisms that cause the competition for resource rents to descend into outright warfare. Ultimately, greed theory is unsatisfactory, even its new guise as a feasibility hypothesis. This is because

\footnotetext{
${ }^{5}$ In 2005, an entire issue of the Journal of Conflict Resolution, 49 (4) called Paradigm in Distress, was devoted to demonstrating the non-robustness of the main conclusions of Collier and Hoeffler greed hypothesis
} 
conflict is rarely a rational, Pareto optimal strategy, except in circumstances illustrated by the Hirshleifer (1995) and Skaperdas (1992) models discussed above where property rights are absent and the possibilities of exchange limited. More generally it points to institutional failure which encourages noncontractual behaviour, as well as the existence of asymmetric information. The presence of grievances is necessary for group formation and violent collective action, and this is what we now turn to.

\section{Grievances and Horizontal Inequality as Conflict Drivers}

In the context of civil war or rebellion, grievance is sometimes described as a justice-seeking motivation. The discussion in this section on grievances begins with grievance based theories of conflict before moving on to measurement issues.

\subsection{Theories of Grievance}

Central to grievances is identity and group formation. An individual's utility may be related to his identity, specifically the relative position of the group he identifies with in the social pecking order; see Akerlof and Kranton (2000). An individual may derive utility from certain normative forms of behaviour appropriate to his identity but considered deviant by other groups, and may even face sanctions from like-minded group members if he deviates from them. This type of behavioural paradigm may be related to solving the collective action problems (Olson, 1965), without which organised large-scale violence is impossible, even if we believe conflict is primarily motivated by greed. As noted in the introduction, some appropriate definition of ethnicity may be a superior basis for group formation compared to social class in an ethnically homogenous society.

We sub-divide theories of grievance into relative deprivation, polarization and horizontal inequality. While it is important to differentiate them, some overlap among the three definitions are inevitable.

\section{Relative deprivation}

The notion of relative deprivation dates back to the work of Ted Gurr (1970) who defines it as the discrepancy between what people think they deserve, and what they actually believe they can get; in short the disparity between aspirations and achievements. Thus, educational achievements may raise the aspirations of young people, but they will become frustrated if unemployed, occasionally venting their feelings in mass political violence. Gurr puts forward the following hypothesis, 'the potential for collective violence varies strongly with the intensity and scope of relative deprivation among members of a collectivity' (p.24). This lays down the notion of relative deprivation as the micro-foundation for conflict. Relative deprivation is considered to be a major cause of civil war, as well as sectarian and routine violence.

The applications vary across ethno-communal lines, regional boundaries, societal class, or just the feeling of being relatively deprived vis-à-vis the general situation. In the eastern Indonesian province of Maluku, the 
traditionally privileged Christians group felt relatively deprived against the rising Muslim community economically and politically, which resulted in the bloodiest Muslim-Christian conflict in the country's history (Tadjoeddin, 2003). Similar statements centring around unemployment could be made about the Catholic-Protestant cleavage in Northern Ireland. In Nepal, the lack of development in remote rural districts of the country fuelled the Maoist insurgency (Murshed and Gates, 2005).

Another type of violence can be described as 'routine'. Tadjoeddin and Murshed (2007) examine the socio-economic origins of this type of violence in Java, Indonesia. It is centred on vigilante violence/popular justice and intergroup/neighbourhood brawls. Routine violence covers group or collective violence, and it is different from individual violence, domestic violence, or homicide-which can simply be labelled as crime. The theoretical underpinnings for routine violence are similar to those utilised to explain mass political violence short of internal war in Hibbs (1973). Using panel data analysis of count data, Tadjoeddin and Murshed (2007) examine the relationship between routine violence on one hand, and growth, poverty, and level of development (including education) on the other hand. The relationships between violence and the levels of education and income are non-linear in the form of inverted-U-shape curves. The reason for this is as follows: starting from low levels of average income and educational attainment, when these rise slightly there is much to compete over and quarrel about; this tendency, however, declines with further increases in income and education, as there is much more to lose from violence. Another explanation is the feeling of being relatively deprived since rising education is not automatically followed by rising income.

\section{Polarisation}

A related notion is that of polarisation; see Esteban and Ray (1994) on this. Polarisation occurs when two groups exhibit great inter-group heterogeneity combined with intra-group homogeneity. Economic polarisation (along with high vertical income inequality) can occur in societies that are culturally homogenous. Ethnic polarisation could, in principal, exist along with a degree of economic equality. What is useful is a hybrid concept that combines identity and economic polarities, as in Østby (2008). In their original and seminal concept of polarisation, Esteban and Ray (1994) focus on the identification and alienation framework. Their idea is as follows: polarisation is related to the alienation that groups of people feel from one another, and such alienation is fuelled by the feeling of within-group identity. Furthermore, Esteban and Ray argue that the traditional measures of inequality are only concerned with interpersonal alienation, but fail to capture the dimension of group identity. It is important to note that ethnic polarisation requires two or a few ethnicities. When a society has a very large number of identities, then the term ethnic fractionalisation is more appropriate. Therefore, polarization is what may matter for conflict, rather than fractionalisation and/or overall vertical (interindividual) inequality. Few studies have empirically demonstrated the existence of such an argument. Montalvo and Reynal-Querol (2005) find that ethnic polarisation is a significant explanatory variable for civil war onset, while ethnic fractionalisation is not. 


\section{Horizontal inequality}

The notion of horizontal inequalities between groups, classified by ethnicity, religion, linguistic differences, tribal affiliations etc., is thought to be an important cause of contemporary civil war and sectarian strife, but not routine violence. The idea of horizontal inequality may overlap with the notion of relative deprivation and polarisation as will be indicated by alternative measures discussed below. The expression, horizontal inequality, originates in the work of Frances Stewart; see Stewart (2000), and should be distinguished from vertical inequality, which is the inequality within an otherwise homogenous population. Four sources of horizontal inequality may be highlighted:

o Discrimination in Public Spending and Taxation. Discrimination in the allocation of public spending, and unfair tax burdens, lead to serious unrest. Grossman (1991) develops a theoretical model of insurrection against the state by the peasantry reacting to over taxation, where the state is a tax-farmer interested in maximising the income of the rentier class. Discrimination in the allocation of public employment is particularly resented in societies in which public employment represents the principal avenue for personal advance, as in Burundi. In addition, the over taxation of smallholders encourages insurrection, and indigenous peoples often face discrimination in access to schooling, health care, and public-sector jobs; many of these factors are present in Nepal's current civil war, see Murshed and Gates (2005). Where there are inter-group fiscal transfers, which may take the form of spending on education and health for disadvantaged groups, or including them in government employment, commitment to the transfer by those in power may be imperfect. This lack of credibility can eventually lead to civil war.

o High Asset Inequality. Agrarian societies with high inequality-for example El Salvador, Guatemala, Nepal, the Philippines, and Zimbabwe-have high asset inequality, and are very prone to conflict, see Russet (1964) for an early view on this. Asset redistribution such as land reform to lessen inequality is more difficult than public finance reform. Besançon (2005), however, points out that purely ethnic conflicts, as opposed to revolutions and genocides, are more likely when a greater degree of income equality has been achieved between contending ethnic groups. Inclusion in the political process is more crucial to preventing this type of conflict, which are not usually civil wars, as the state is not involved.

- Economic Mismanagement and Recession. In Africa, Latin America and the former Soviet Union conflict ridden countries have also suffered prolonged economic mismanagement and growth collapse. Successive IMF and World Bank supported adjustment programmes in DRC-Zaire, Somalia and elsewhere not only proved incapable of promoting economic recovery, but given the level of corruption within the state, themselves became targets for capture by elite groups. Economic mismanagement is often associated with an uneven and unfair 
distribution of the burdens of subsequent adjustment; public spending benefiting the elite and the military is protected, often favouring particular ethnic groups, with the burden of adjustment placed on expenditures of value to the poor and disadvantaged groups. Also, as Rodrik (1999) emphasises, countries with weak institutions of conflict management, as well as high income inequality are less able to withstand economic shocks and experience growth failure. They are also more prone to the risk of civil strife and war, since their weak institutions, which are further weakened by shocks and lower growth, are unable to contain the resulting social pressure and distributional conflict.

Grievances Related to Resource Rents: Natural resource rents can by themselves become a source of grievance, if local populations feel that they are not getting a fair share of these, as in the Niger Delta region of Nigeria. It can also cause secessionist tendencies amongst relative rich regions, who no longer want to subsidise their fellow countrymen, as in the case of Aceh in Indonesia, see Tadjoeddin et. al. (2003).

\subsection{Measurement of Grievance}

Relative deprivation

A simple starting point in measuring relative deprivation is to calculate the simple ratio (or difference) between two competing groups on particular socioeconomic indicators, and examine their evolution over time. A worsening ratio for one group means an improving ratio for the other which may be perceived by the deprived group as unjust. Stewart (2000) applied the method to nine cases of internal conflict and social violence and shows that widening socioeconomic horizontal inequalities over time contribute to ethnic violence. However, this measure can be also interpreted as a measure of horizontal inequality since it measures the socio-economic distance between two groups and their movement over time.

A second practical measure is utilised by Murshed and Gates (2005), in a cross sectional approach, by calculating the gap of the human development index between sub-national entities (districts) in Nepal with its national capital, Kathmandu, which has the highest human development score. ${ }^{6}$ The gap can be interpreted as the extent of deprivation relative to the capital's urban and modern economic development. However, this measure can also be interpreted as spatial horizontal inequality, according to Murshed and Gates (2005). This gap measure can also be measured using a certain national average. ${ }^{7}$ Within country, disaggregated data on the human development index is collected for many countries in Asia and Latin America. This data is usually available spatially --across provinces or districts. But, in some cases we can impute group inequalities from spatial data, because certain ethnic groups chiefly reside in particular areas. In a few instances, household surveys also explicitly ask questions about the ethnicity of households. If that is the case, we can compute differences (gaps) in income, poverty incidence,

\footnotetext{
${ }^{6}$ The human development index is an un-weighted average of per-capita income, educational status and longevity.

${ }^{7}$ Analogies with the poverty-gap measure are appropriate.
} 
educational and health status across ethnic groups. Such data, for example, is recently available for Indonesia.

\section{Polarisation}

Esteban and Ray (1994) pioneered a polarisation measure, called the ER polarisation index. The index is more about social polarisation rather than identity based inequality. ${ }^{8}$ The formula contains a subjective measure of $\alpha$ whose purpose is to increase the weight given to large groups, so that the index rises as the population is distributed among fewer and more equally sized groups. Another polarisation measure is proposed by Zhang and Kanbur (2001). The Zhang-Kanbur (ZK) polarisation index is the ratio of the between group and within group inequality based on their respective Theil index. The ZK index emphasizes the role of within-group inequality by implying that lower within-group inequality would increase the polarisation measure, an aspect that is missing in the ER polarisation measure.

\section{Horizontal inequality}

Horizontal inequality is a relatively new concept, not only is its measurement thwarted by the paucity of data on relevant ethnic groups, but no real theoretical consensus exists as yet on a metric for its measurement. But for a variety of purposes, including cross-national comparisons, a single index number type measure of horizontal inequality is required, similar to the GINI coefficient for vertical inequality. We also need to be clear as to which groups we wish to apply this idea to: linguistic, tribal, religious and so on, as there may be some overlap across these categorisations. For example, in diverse countries such as India or Indonesia, horizontal inequalities across linguistic lines will be different from those along a confessional basis. A good summary of the literature can be found in Stewart, Brown and Mancini (2005).

As a starting point, such an index should be objective (descriptive) and not subjective (evaluative), as is the case for example with the Atkinson subjective measure of inequality aversion. Secondly, as far as its application to conflict is concerned we would probably be more interested in between group inequality rather than the inequality within groups. So, for example if we want to examine the horizontal inequality between Hutus and Tutsis in promoting conflict in Burundi and Rwanda, we might be less interested in the inequalities that exist within each group, than between groups, but we are concerned with group sizes. Stewart, Brown and Mancini (2005) distinguish between inequality measures that are specifically designed to measure differences across different identity based groups, and those that adapt of existing measures of vertical inequality. Chief among the former are the Esteban-Ray index and the Zhang-Kanbur index. In the second category of measures, those already in use in measuring vertical inequality, the two most promising are the population weighted coefficient of variation ${ }^{9}$ and the group GINI coefficient ${ }^{10}$; see Stewart, Brown and Mancini (2005) for details.

\footnotetext{
${ }^{8}$ An ethnically homogenous society may be highly polarised, with most people being either rich or poor.

${ }^{9}$ The coefficient of variation is the variance divided by the mean. Population weighting may be appropriate as they correct for large variations owing to small population groups.

${ }^{10}$ The GINI compares differences between all groups.
} 


\subsection{Some Empirical Findings}

Horizontal inequalities have been found to significantly affect conflict in Nepal and Indonesia, to cite two examples of its application to individual nations. Nepal had a Maoist armed insurgency since 1996, which has recently subsided. Based upon data on human development indicators at the district level in the year of the conflict onset in Nepal in 1996, Murshed and Gates (2005) find that HDI gaps with the capital Kathmandu, as well as greater landlessness, significantly explain the intensity of conflict-related fatalities across different districts in Nepal, whereas natural resources do not. Thus variables of enduring grievance such as landlessness are the most significant compared to more temporary income differences; at the same time the greed hypothesis is invalidated.

Indonesia is plagued by several conflicts, some of which are secessionist in nature, others are inter-communal. Four resource natural rich provinces: Aceh, Riau, East Kalimantan and Papua have wanted to separate from the federation. Brown (2005) argues that the socio-economic achievements (in terms of jobs and education) of the native Acehnese declined during periods when GRDP (regional income) rose substantially. This rise in GRDP took place because of the presence of oil and gas in Aceh. For example, poverty in Aceh rose by $239 \%$ during $1980-2002$, whereas it fell by $42 \%$ in the rest of Indonesia. In Aceh, income (GRDP) per capita is 39\% greater than the Indonesian average but expenditure per head, after redistribution through the fiscal system, was $18 \%$ below the national average. In Papua (rich in copper and silver), income per capita was $65 \%$ above the national average before the fiscal system came into operation. After taxes and subsidies, expenditure is $9 \%$ below the Indonesian average and there is a higher incidence of poverty, particularly amongst indigenous peoples. Thus, these separatist tendencies, in whole or part, are a reflection of the dissatisfaction in some of the richer and natural resource endowed areas with the federal authority's redistributive policies taxing richer provinces to subsidise poorer regions. Ethno-communal violence can be explained by differences in district health status, measured by a horizontal inequality index (population weighted coefficient of variation); see Mancini (2005). Tadjoeddin (2003) finds interesting results in this connection. Converging gaps in socio-economic achievements of the two competing groups contribute to ethnic violence amongst Muslims and Christians in Maluku, whereas widening indicators have contributed to Dayak-Madurese violence in Kalimantan. The latter point has also been emphasised by Besançon (2005). What matters is the perception of change in the relative position of each ethnic group's rival community.

Østby (2008) manages to construct polarisation indices and horizontal inequalities across 36 developing countries during 1986-2004 based on ownership of consumer durables (which she uses to calculate measures referred to as economic) and educational attainment (which she uses to calculate measures referred to as social) based upon household surveys. The data is drawn from demographic and health surveys (DHS) and does not contain information on income or wealth. Be that as it may, this represents a 
pioneering application to the cross-country conflict debate. In her panel and cross-sectional analysis, she finds that social and economic polarisation, ${ }^{11}$ and social horizontal inequality based on education significantly contributes to conflict, whereas vertical inequality and purely ethnic or socioeconomic polarisation do not. A priori, one would expect more enduring horizontal inequalities based on health, education, political exclusion and asset holdings to be more significant compared to transient income differences. Østby (2006) utilises the same data set on horizontal inequalities along with a variety of political variables ranging from democracy to political inclusiveness. The idea is that democracies and semi-democracies may facilitate the transformation of horizontal inequalities into conflict, by permitting protest. This theoretical assertion is supported by her empirical analysis. Inclusiveness implies an electoral system which has greater characteristics of proportional representation, and where minority groups are allowed to participate in elections. Inclusiveness, combined with high horizontal inequality and democracy can exacerbate conflict at low levels of economic development. Thus, what is needed for peace is economic development and reduced horizontal inequalities in parallel with democratic development and inclusiveness. Despite the paucity of data on horizontal inequality, reasonable proxies show that it does matter in explaining conflict onset in a cross-section of countries, in contrast to the earlier assertions by many that inequality was immaterial to conflict risk.

Three further points are worth emphasising at this juncture. First of all, horizontal inequality has to be measured at the level of the nation state. In a sense it refers to cross-sectional variation within a specific country. The data in different countries on horizontal inequality is still embryonic. Indices for horizontal inequality can be used for cross-country comparisons, whereas for a single conflict onset, gap measures may be sufficient. Secondly, most nation states do not keep detailed or systematic data on group inequalities (say between Catholics and Protestants, Hutus and Tutsis, Muslims and Christians etc.) because of obvious political sensitivities. However, ethnic questions in future household surveys across the developing world will go a long way in helping us to enumerate data on inter-group differences in socioeconomic achievement. Finally, horizontal inequality as a cause of conflict can work in two directions, the rich may initiate conflict to extricate themselves from the relatively poor (the rage of the rich), or the poor may rise up in revolt against the rich (the rage of the poor). The former may be more likely in cases where a region suddenly discovers it can exist viably on its own resources, thus wishing to secede and not hand over revenues to the rest of the country. The latter is more likely to manifest it self in rebellions and revolutionary attempts to overthrow an oppressive state.

\section{Synthesis and Social Contract}

The greed versus grievance dichotomy is a useful entry point into the debate about the causes of conflict. In certain instances, where there are substantial quantities of capturable natural resource wealth present such as alluvial

\footnotetext{
${ }^{11}$ Economic polarisation becomes insignificant in the cross-sectional regressions.
} 
diamonds, oil or drugs, greed may be the dominant factor prolonging conflict, but without group formation (for which some historical grievances are important) violent collective action cannot take place. In short, grievances can be present without greed, but it is difficult to sustain greedy motives without some grievances. Although greed and grievance are regarded as competing views, yet they may be complementary, as greed may lead to grievances and vice versa. The greed or grievance explanations (or some hybrid form of both) may be necessary for the outbreak of civil war, but arguably they are not sufficient. This is because the causes enumerated in the two sections above contribute to the risk of civil war, yet some societies despite having conditions pre-disposing them to civil war, such as horizontal inequality, polarisation and natural resource rents, do not descend into conflict. We argue that for the forces behind either greed or grievance to take the form of large-scale violence there must be other factors at work, specifically a weakening of what Addison and Murshed (2001) call the 'social contract' (see also Murshed, 2002). This is similar to the weak state capacity, and by implication poor institutional quality, arguments made above. Therefore, even if rents from capturable resources do constitute a sizeable prize, violent conflict is unlikely to take hold if a country has a framework of widely-agreed rules, both formal and informal, that govern the allocation of resources, including resource rents, and the peaceful settlement of grievances. Such a viable social contract can be sufficient to restrain, if not eliminate, opportunistic behaviour such as largescale theft of resource rents, and the violent expression of grievance.

War implies the absence or breakdown of contractual interaction, as indicated earlier. In traditional international relations theory, if nation states exist in a state of anarchy vis-à-vis each other, they may make war with each other if it is in their interests, a point also emphasised by the great philosopher Immanuel Kant in 1795. One, however, expects the presence of some degree of contract or consent within the modern nation state. Consequently, civil war is a reflection of the breakdown or degeneration of a contract governing interactions between various parties. Hirshleifer (1995) draws our attention to the fact that within a society, social contracts can be vertical if they are authoritarian in the sense of Thomas Hobbes, or they may be horizontal if fashioned with popular consent, as advocated by John Locke. The former may be described as dictatorial, and the latter as democratic. What constitutes the basis for a good social contract? Kant's (1795) ${ }^{12}$ essay on the 'Perpetual Peace' provides us with the fundamental clues in this direction. First, observe the usage of the expression 'perpetual', implying permanence as opposed to a transient truce. In the contemporary parlance of game theory, such agreements or contracts would be described as re-negotiation proof or self-enforcing, so that there are no incentives to deviate from it. Secondly, and most crucially, Kant refers to a 'republican' constitution. By this he means the separation of powers ${ }^{13}$ between the executive and legislature (this ensures their proper and efficient functioning), and we may also add the independence

\footnotetext{
12 Although Kant speaks about a perpetual peace between nations, we can extend his argument to groups within a nation state.

${ }_{13}$ Despotism is when there is no separation of powers; those who administer laws are one and the same as those who decree them. Despotism is not simply confined to absolute monarchy or dictatorship, but can also be a feature of flawed democracies.
} 
of the judiciary. Put simply, this concept implies good government that holds the social contract together. Our contemporary understanding of good governance can include a host of other factors beyond the separation of powers, such as decentralized decision making powers. Thirdly, the stability of the peace depends upon the source of sovereignty or legitimate power within the nation. Although not enamoured of certain forms of rabble-led democracy, Kant nevertheless points out that good governance provided by a dictator or an absolute monarch is inherently unstable as he or his successors face temptations to deviate from good government, and the assurance of good governance is more forthcoming in a system of power that is representative of the people. ${ }^{14}$ To Kant's list of conditions for a perpetual peace (what we refer to as a stable social contract) we could add an all encompassing degree of economic interdependence manifested in peaceful economic exchange. The fact that commerce promotes peace was also pointed by Tom Paine (1791-2, page 265). Just as war between nations becomes less likely, due to their mutual all encompassing non-violent economic interdependence, the same argument can be made for competing groups within a nation state. It is because of the lack of economic development, evidenced by a relatively smaller manufacturing sector, and a low per-capita income (implying less exchange), that leads to what Humphreys (2005) describes as sparse economic interaction, which makes wars between competing groups more likely, as they have less to lose from the collateral damage and destructiveness of war. Thus war, or the breakdown of the social contract, is more likely when there is economic underdevelopment, the result of a poor growth record. Interestingly, Kant (1795) and Paine (1792, p 320) point to a form of the greed hypothesis, which may explain colonial wars aimed at expropriating resources from inhabitants of distant lands, considered to be outside the pale of 'civilization'.

So what factors lead to the breakdown of the social contract within a nation state? What circumstances create incentives for groups within societies to choose war rather than resolve disputes peacefully? Clearly these seem to occur in failing states. Yet, the eponymous term 'failed state' may be too vague and unhelpful in this regard. Among the various factors, three reasons may be highlighted. The first refers to the fiscal and revenue sharing agreements the state (or those in power) have with various stakeholders, and the breakdown of these arrangements can produce greed and/or grievance. Secondly, there is the political system. In the face of an unstable polity where the separation of powers and the sources of (legitimate or illegitimate) power are inherently unstable, it is important to focus on individual incentives faced by rulers that may or may not cause them to promote development and modernisation. Thirdly, the famous Lipset (1960) modernisation hypothesis states that demands for democracy surely follow economic development and the attainment of a high standard of living; once a particular (high) level of

\footnotetext{
${ }^{14}$ The $18^{\text {th }}$ century English poet Alexander Pope had, by contrast, asserted that the form of government or source of power was immaterial in the presence of good governance:

"For forms of government let fools contest

Whate'er is best administered is best"

[Alexander Pope, Essay on Man, 1707].
} 
average income is achieved violence becomes a very costly means of settling disputes. The road to peace and democracy is therefore along sustained economic growth, and, therefore, the real culprit as far as the breakdown of the social contract is considered could be growth failure in low-income developing countries because it creates conditions where violence is more attractive. Low growth also implies a more undiversified economic structure, increased susceptibility to terms of trade shocks and dependence on external aid.

Within nation states, the fiscal system will secure a workable social contract if the allocation of public expenditures and the apportionment of taxes are judged to be fair, or at least not so unfair that some groups judge taking resources by force the better option. There are many examples of conflicts emerging out of fiscal disputes. Côte d'Ivoire, for instance, became unstable with the collapse of the social contract engineered by the late President Houphouët-Boigny, in which he allocated public spending across the regions to successfully buy the loyalty of the country's ethnic groups. Disputes over the apportionment of revenues from natural resources are especially common and, as in Indonesia and Nigeria, these take on ethnic and regional dimensions. Contemporary civil wars are more often related to the breakdown of explicit or implicit arrangements to share resources or revenues, rather than the absence of an agreement to share resources or rents. One reason that a contract to share revenues encounters difficulties is the imperfect credibility with which the side that controls the 'pot' honour's its commitment. There may be two parties to the potential armed conflict, say a government and a rebel group, where the government party has access to revenues and royalties, but is threatened by the excluded rebel group which may violently overthrow the government as in Addison and Murshed (2001). On the other hand, the rebels may choose not to fight if they receive a fiscal transfer from the government. Similarly, the government has a choice between fighting the rebels and offering it a fiscal transfer. A feasible social contract favouring peace must give the rebels as much utility via a credible transfer as they would get in the event of a probable overthrow of the state. A social contract favouring peace in return for a transfer is infeasible if the probability of toppling the government by war is greater than the chances of its credibly making the transfer. Also the social contract is less likely with regimes that prefer military expenditure over making a fiscal transfer to the rebels, common in countries with powerful militaries. There is, therefore, a trade-off between military expenditure and a credible transfer. When the transfer is highly improbable, and the potential spoils rich, warfare is more likely.

Conflict-affected nations have histories of weak social contracts (or a once strong social contract that has degraded). This weakness is in many instances a legacy of colonialism which institutionalised mechanisms favouring settlers over indigenous peoples (Guatemala, Zimbabwe, South Africa); divide and rule favouring one ethnic group over another, as in Rwanda; market controls to create rents for settlers to the cost of locals (Zimbabwe); and the expropriation of land and resource rents (Angola, and the Belgian Congo). 
Hegre et. Al. (2001) point out that the risk of conflict is lower in both well established democracies and autocracies. It suggests that conflict risk is at its highest during transitions to and away from democracy when state capacity is weak, and also in fledgling and imperfect democracies (anocracies). Most developing countries are imperfect democracies, or at any early stage of the democratic transition. A final complexity in fatally weakening social contracts was the interaction of these 'domestic' factors with external events, notably the Cold War, which provided finance and ideological succour to ruling elites and rebels. The net result of these processes is the accumulation of grievances within the context of a disintegrating social contract that would otherwise have provided the rules of the game to govern the distribution of the social pie and to achieve peaceful conflict resolution. These circumstances can also promote greed-based motivations aimed at controlling natural resources.

With regard to incentives faced by rulers in developing countries, it has to be remembered that until the end of the cold war most developing countries were ruled by strong men. Some promoted development, others did not. Dunning (2005) makes an argument, based on a two period-two agent-two sector game theoretic model, about choices by rulers regarding the future growth path of the economy in the context of natural resource abundance. He compares Mobutu's Zaire (1965-1997) to Suharto's Indonesia (1965-98) and Botswana during the same period. In Botswana, revenues from Kimberlite diamonds were very stable, due to Botswana's unique relationship with De Beers and its important position as a major supplier. It did not need to diversify it economy. But it chose a developmental path because of the mature nature of political elites there. In Indonesia and Zaire resource flows were volatile. In one case the dictator (Suharto) chose diversification and growth enhancing strategies, as well as policies aimed at equalisation and poverty reduction to contain political opposition. Development in Indonesia was impressive, and may have led, at least partially, to endogenous demands for democracy (Lipset, 1960). In the other case (Zaire, now DRC), Mobutu did not, because he felt that diversification and investment in infrastructure would loosen his grip on power and strengthen political opposition to him based on ethnicity. Zaire or the DRC has perhaps the poorest post-1960 growth record in the planet. Perhaps, in East Asia greater fears of communism strengthened benevolence in dictators (South Korea, Taiwan, Singapore and Indonesia), whereas in Africa a certain type of factionalism dominated policies and politics, retarding growth enhancing economic diversification and infrastructural development.

Turning to the all encompassing importance of growth in promoting peaceful economic interaction and the social contract, it is worth while examining a few of the broad stylized facts regarding conflict across developing countries since about 1960. To get an empirical feel for some of these macro-channels, a descriptive look at the data may be in order. Table 1 gives us 17 countries with the highest conflict incidence since $1960,{ }^{15}$ along with their average

\footnotetext{
${ }^{15}$ We have excluded Israel with 49 years, as it is a rich country when one excludes the Palestinian territories, as well as Cambodia (36 years) and Yemen (23 years) because of the paucity of economic data.
} 
annual long-term growth rates of per-capita income accompanied by the typology of the economy and the most frequently occurring regime type. In table 1, we compare growth rates, the combined democracy and autocracy score known as Polity 2, endowment type and conflict intensity or incidence in selected developing countries during the period 1965-2000. The Polity score is an imperfect proxy for institutional capacity and governance, but we have good time series data on these. This is coded 1 for autocracies (those with an autocracy score below -4), 3 for democracies (for democracy scores above 4) and 2 for anocracies that have both democratic and autocratic characteristics (with scores of between -4 and 4). The endowment typology is based upon a country's principal exports, ${ }^{16}$ and is subject to change. Note that countries can have more than one year of civil war in any given calendar year if there are several conflicts taking place within the nation simultaneously (Burma, India, Ethiopia, Philippines, Iraq and Angola). Also, incidence does not imply anything about conflict intensity, which is measured by fatalities.

Table 1: Conflict Years, Growth, Polity and Economic Typology in Selected Countries

\begin{tabular}{|l|l|l|l|l|}
\hline Country & $\begin{array}{l}\text { Conflict } \\
\text { incidence } \\
\text { in years, } \\
\mathbf{1 9 6 0 - 2 0 0 0}\end{array}$ & $\begin{array}{l}\text { Most } \\
\text { frequent } \\
\text { regime type }\end{array}$ & $\begin{array}{l}\text { Annual average } \\
\text { Per-capita } \\
\text { income } \\
\text { Growth rate } \\
\mathbf{1 9 6 5 - 1 9 9 9}\end{array}$ & Economic typology \\
\hline $\begin{array}{l}\text { Burma } \\
\text { (Myanmar) }\end{array}$ & 177 & 1 & $1.5 \%$ & Diffuse, Point \\
\hline India & 104 & 3 & $2.4 \%$ & Manufacturing \\
\hline Ethiopia & 81 & 1 & $-0.3 \%$ & Coffee/Cocoa \\
\hline Philippines & 59 & $1 ; 2 ; 3$ & $0.9 \%$ & Diffuse, \\
Manufacturing
\end{tabular}

Sources: Conflict years at http://www.prio.no/cwp/ArmedConflict; UNCTAD data base and Murshed (2004) for the typology of the economy; Polity data at www.cidcm.umd.edu/insr/polity; and World Development Indicators (2002) for growth rates.

Only five of these high conflict incidence nations reported in Table 1 have a per-capita income growth rate in excess of $2 \%$ per annum in the long-term: Indonesia, India, Sri Lanka, Colombia and Uganda. Generally speaking, poor growth performers have more conflict years in Table 1. Only four economies (India, Philippines, Sri Lanka and Mozambique) have not been point-source (mineral/fuel exporting) or coffee/cocoa economies (the Burmese conflicts are fuelled by trade in illegal substances which cannot be reported here, because

\footnotetext{
16 This is based on a country's principal exports, which are described as point (mineral or fuel), coffee-cocoa, diffuse (other agricultural) or manufacturing.
} 
of data paucity). This lends some support to the arguments made in section 2 regarding conflict and its association with natural resources across countries.

Murshed (2006) points out that only four point-sourced and three coffee/cocoa based economies have had growth rates of over $2 \%$ per annum in per-capita income. Botswana and Indonesia are the best performing point-sourced economies. Furthermore, only three point-sourced countries and four coffee/cocoa economies did not descend into some form of civil war, as noted in Murshed (2006). Diffuse economies also have conflict; examples of the high incidence of civil wars occurring in diffuse economies are in South Asia, the Philippines and Burma, as well as Mozambique and Zimbabwe in Africa. In total, eight out of thirty diffuse economies have avoided civil war, a record that is better than for point-sourced and coffee/cocoa based economies. Two prominent examples of growth failures not experiencing civil war are Tanzania and Zambia. Notwithstanding India, manufacturing exporters are least likely to experience outright civil war. Perhaps, this is because they have the best growth rates and institutional quality. They are also more diversified economies, and are able to withstand the commodity price and national income fluctuations that make growth failure more likely. Growth also needs to be pro-poor, which ultimately means less inequality, so as to minimise the effects of horizontal inequalities and polarisation.

It is discernable that India, Sri Lanka and Colombia are the stable democracies in the post 1960 era that have had civil wars, including high intensity conflict. Many of the transitions in regime type from autocracy to anocracy to democracy (during 1960-2000) are described in Murshed (2006). Multiple switches in all directions are possible, and not just from autocracy to democracy. Nevertheless, only 5 out of the seventeen nations with a high conflict incidence have ever been democracies with a democracy score over 4. Democracy, even stable democracy, does not guarantee the absence of armed conflict, both of the secessionist and rebel varieties, as the examples of India, Colombia, Sri Lanka, the Philippines and others indicate. Autocracies also fall into conflict; nevertheless, stable autocracies such as China and Singapore have avoided civil war, as did Taiwan and South Korea which became democracies recently. Despite prominent outliers such as India, Colombia, and Saudi Arabia, most conflict prone countries are neither stable democracies nor autocracies, lending support to the Hegre et. al. (2001) finding that conflict risk is greatest when regime types are in transition, say from autocracy to democracy.

In summary, the breakdown of the social contract captures institutional malfunctioning, the counterpart of the mechanisms in the middle of the greed hypothesis discussed in section 2; it is also crucial in transforming grievances into collective violence. A failing social contract may be the real signal of the risk of civil war, for the purposes of conflict prevention.

\section{Conclusions}

Pure versions of the greed hypothesis are, on their own, unsatisfactory explanations for the causes of conflict. Addison, Le Billon, and Murshed 
(2002) construct a game-theoretic model of contemporary conflict involving the competition for resources combined with historical grievances. In addition to resource rents, grievances also play their part in fuelling conflict by explaining inter-group non-cooperation and serving to lower the cost of participation in conflict. Conflict can increase because of heightened intrinsic grievances, or because there are more lootable resources. In reality the competing greed versus grievance hypotheses may, after all, be complementary explanations for conflict. Insofar as they do provide alternative views, a fair test for their relative explanatory powers is best conducted at the level of a quantitative country-case study, because cross-country comparisons of horizontal inequality are still at very early stages of development due to the lack of data. Indonesia's resource rich regions that have had separatist conflicts with the federal government offer us a striking contrast in trying to gauge the relative explanatory power of the greed versus grievance explanations for conflict. When viewed via the lens of a detailed quantitative case study, the grievance and horizontal inequality explanations dominate any greed motivation. Yet, when looked at as one observation among many through the prism of a cross-country study, Indonesia's resource-rich reasons are examples of a modified form of the greed explanation (resources helping to prolong the duration of conflict and encouraging secession). It would appear, therefore, that the greed explanation for conflict duration and secessionist wars works in cross-country studies, but has to make way for grievance-based arguments in quantitative country-case studies. Grievances and horizontal inequalities may, after all, be better at explaining why conflicts begin, but not necessarily why they persist. Neither the presence of greed or grievance is sufficient for the outbreak of violent conflict, something which requires institutional breakdown which we describe as the failure of the social contract.

As yet, no empirical models at the level of cross-national analysis exist to properly test for the relative power of greed vis-à-vis horizontal inequality type grievances in explaining conflict onset. This is not just a result of constraints posed by insufficient data. Greed and grievance can and do co-exist; because one breeds the other a model of their simultaneous determination is required, along with the contribution of poverty (which is chiefly about the lack of growth) and institutional quality. Furthermore, the existing econometric literature regarding the causes of conflict allows us to infer little about the true nature of the causal links between the phenomena examined. Tests for causality require sufficiently long time series data; unless techniques of dynamic panel data analysis are employed, inferences about causality will remain limited in nature.

Despite these shortcomings, a review of the existing empirical literature on the causes of conflict informs us that the most robustly significant predictor of conflict risk and its duration is some indicator of economic prosperity (or lack of poverty) such as income per-capita within a cross-section where average income does vary. This is because at a higher income people have more to lose from the destructiveness of conflict (Lipset, 1960); and higher per-capita income implies a better functioning social contract, institutions and state capacity. Above all, there is less poverty; masses of impoverished individuals 
provide the best recruitment grounds for rebel fighters. Ultimately, the political economy of growth failure and institutional degradation must inform us about the causes of conflict, along with theories of deprivation and alienation.

\section{REFERENCES}

Addison, Tony and S. Mansoob Murshed (2001). 'From Conflict to Reconstruction: Reviving the Social Contract', UNU/WIDER Discussion Paper 48, Helsinki: UNU/WIDER, www.wider.unu.edu/publications/publications.htm.

Addison, Tony, Philippe Le Billon and S. Mansoob Murshed (2002). 'Conflict in Africa: The Cost of Peaceful Behaviour', Journal of African Economies 11 (3): 365-86.

Akerlof, George and Rachel E. Kranton (2000). 'Economics and Identity', Quarterly Journal of Economics 115(3): 715-753.

Besançon, Marie (2005). 'Relative Resources: Inequality in Ethnic Wars, Revolutions and Genocides', Journal of Peace Research 42(4): 393-415.

Brown, Graham (2005). 'Horizontal Inequalities, Ethnic Separatism, and Violent Conflict: The Case of Aceh, Indonesia', Background paper for Human Development Report 2005, UNDP.

Brunnschweiler, Christa N. and Erwin H. Bulte (2008). 'Natural Resources and Violent Conflict: Resource Abundance, Dependence and the Onset of Civil Wars, Economics Working Paper Series 08/78, ETH Zurich.

Collier, Paul and Anke Hoeffler (2002). 'On the Incidence of Civil War in Africa', Journal of Conflict Resolution 46(1): 13-28.

Collier, Paul and Anke Hoeffler (2004). 'Greed and Grievance in Civil Wars', Oxford Economic Papers 56(4): 563-595.

Collier, Paul, Anke Hoeffler and Mans Soderbom (2004). 'On the Duration of Civil War', Journal of Peace Research 41(3): 253-73

Collier, Paul, Anke Hoeffler and Dominic Rohner (2007). 'Beyond Greed and Grievance: Feasibility and Civil War', CSAE WPS/2006-10, Oxford: University of Oxford.

Collier, Paul, Lani Elliot, Håvard Hegre, Anke Hoeffler, Marta Reynal-Querol and Nicholas Sambanis (2003). Breaking the Conflict Trap: Civil War and Development Policy, World Bank, Oxford: Oxford University Press.

De Soysa, Indra (2002). 'Paradise is a Bazaar? Testing the Effects of Greed, Creed, Grievance and Governance on Civil war, 1989-1999', Journal of Peace Research 39(4): 395-416.

De Soysa, Indra and Eric Neumayer (2007). 'Resource Wealth and the Risk of Civil War Onset: Results from a New Dataset on Natural Resource Rents, 1970-99', Conflict Management and Peace Science, forthcoming. 
Dunning, Thad (2005). 'Resource Dependence, Economic Performance, and Political Stability, Journal of Conflict Resolution 49(4): 451-82.

Edgeworth, Francis Y. (1881). Mathematical Psychics, London: C Kegan Paul

Esteban, Joan-Maria and Debraj Ray (1994). 'On the Measurement of Polarization', Econometrica 62(4): 819-51.

Fearon, James (2004). 'Why Do Some Civil Wars Last So Much Longer Than Others', Journal of Peace Research 41(3): 379-414.

Fearon, James (2005). 'Primary Commodity Exports and Civil War', Journal of Conflict Resolution 49(4): 483-507.

Fearon, James and David Laitin (2003). 'Ethnicity, Insurgency and Civil War', American Political Science Review 97(1): 75-90.

Grossman, Herschel I. (1991). 'A General Equilibrium Model of Insurrections', American Economic Review 81(4): 912-21.

Gurr, Ted R (1970). Why Men Rebel, Princeton: Princeton University Press

Gurr, Ted R (2000). Peoples versus States: Minorities at Risk in the New Century, Washington D.C: Unites States Institute for Peace Press.

Harbom, Lotta, Stina Högbladh and Peter Wallensteen (2006). 'Armed Conflict and Peace Agreements', Journal of Peace Research 43(5): 61731.

Hegre, Håvard (2004) 'The Duration and Termination of Civil War', Journal of Peace Research 41(3): 243-52.

Hegre, Håvard, Tanja Ellingsen, Scott Gates and Nils Petter Gleditsch (2001). 'Towards a Democratic Civil Peace? Democracy, Civil Change, and Civil War 1816-1992', American Political Science Review 95(1): 17-33.

Hibbs, Douglas A. (1973). Mass Political Violence: A Cross-National Causal Analysis, London: Wiley.

Hirshleifer, Jack (1995). 'Anarchy and its Breakdown'. Journal of Political Economy 103 (1): 26-52.

Humphreys, Macartan (2005). 'Natural Resources, Conflict, and Conflict Resolution. Uncovering the Mechanisms', Journal of Conflict Resolution 49(4): 508-37.

Kant, Immanuel (1795). Perpetual Peace and Other Essays on Politics, History and Morals, reprinted 1983, Indianapolis: Hackett Publishing.

Lipset, Seymour (1960). Political Man: The Social Bases of Politics, New York: Doubleday.

Lujala, Päivi, Nils Petter Gleditsch and Elisabeth Gilmore (2005). 'A Diamond Curse? Civil War and a Lootable Resource', Journal of Conflict Resolution 49(4): 538-62.

Mancini, Luca (2005) 'Horizontal Inequality and Communal Violence: Evidence from Indonesian Districts', CRISE Working Paper 22, Queen Elizabeth House, University of Oxford. 
Montalvo, Jose G. and Marta Reynal-Querol (2005). 'Ethnic Diversity and Economic Development', Journal of Development Economics 76(2): 293323.

Murshed, S. Mansoob (2002). 'Civil War, Conflict and Underdevelopment', Journal of Peace Research 39(4): 387-93.

Murshed, S. Mansoob (2004). 'When Does Natural Resource Abundance Lead to a Resource Curse', IIED-EEP Working Paper 04-01, www.iied.org.

Murshed, S. Mansoob (2006). 'Turning Swords into Ploughshares and Little Acorns to Tall Trees: The Conflict Growth Nexus and the Poverty of Nations', background paper for the United Nations-Department for Economic and Social Affairs' World Economic Survey, 2006, http://www.un.org/esa/policy/wess/.

Murshed, S. Mansoob and Scott Gates (2005). 'Spatial-Horizontal Inequality and the Maoist Conflict in Nepal', Review of Development Economics 9(1): 121-34.

Olson, Mancur (1965). The Logic of Collective Action, Cambridge MA: Harvard University Press.

Olson, Mancur (1996). 'Big Bills Left on the Sidewalk: Why Some Nations are Rich, and Others Poor', Journal of Economic Perspectives 10(1): 3-24.

Østby, Gudrun (2006). 'Horizontal Inequalities, Political Environment and Civil Conflict', CRISE Working Paper 26, Queen Elizabeth House, University of Oxford.

Østby, Gudrun (2008). 'Polarization, Horizontal Inequalities and Civil Conflict, Journal of Peace Research 45(2): 143-162.

.Paine, Thomas (1791, 1792). The Rights of Man, Reprinted in 1995 as Rights of Man, Common Sense and other Political writings, edited by Mark Philip, Oxford: Classics.

Rodrik, Dani (1999). 'Where Did All the Growth Go? External Shocks, Social Conflict, and Growth Collapses', Journal of Economic Growth 4(4): 385412.

Ross, Michael L. (2001). 'Does Oil Hinder Democracy', World Politics 53(3): 325-61.

Ross, Michael L. (2003). 'Oil, Drugs and Diamonds: The Varying Role of Natural Resources in Civil Wars' in Karen Ballentine and Jake Sherman (eds), The Political Economy of Armed Conflict: Beyond Greed and Grievance, Boulder CO: Lynne Rienner: 47-70.

Ross, Michael L. (2004a). 'Does Taxation Lead to Representation?' British Journal of Political Science 34(2): 229-49.

Ross, Michael L. (2004b). 'What Do We Know About Natural Resources and Civil Wars', Journal of Peace Research 41(3): 337-56.

Ross, Michael L. (2006). 'A Closer Look at Oil, Diamond and Civil War', Annual Review of Political Science 9: 265-300, 
Russet, Bruce M. (1964). 'Inequality and Instability: The Relation of Land Tenure to Politics', World Politics 16(3): 442-54.

Skaperdas, Stergios (1992). 'Cooperation, Conflict and Power in the Absence of Property Rights', American Economic Review 82 (5): 720-39.

Skaperdas, Stergios (2002). 'Warlord Competition', Journal of Peace Research 39(4): 435-46.

Stewart, Frances (2000). 'Crisis Prevention: Tackling Horizontal Inequalities', Oxford Development Studies 28(3): 245-62.

Stewart, Frances, Graham Brown and Luca Mancini (2005). 'Why Horizontal Inequalities Matter: Some Implications for Measurement', CRISE Working Paper 19, Queen Elizabeth House, University of Oxford.

Tadjoeddin, Mohammad Zulfan (2003). 'Communal Conflicts and Horizontal Inequalities in Indonesia: Dynamics and Consequences', presented at the IPSK-CNRS Group Meeting on Conflict, LIPI Jakarta, 15 January.

Tadjoeddin, Mohammad Zulfan and S. Mansoob Murshed (2007) 'Socioeconomic Determinants of Everyday Violence in Indonesia: An Empirical Investigation of Javanese Districts, 1994-2003', Journal of Peace Research, 44(6): 689-709.

Tadjoeddin, Mohammad Zulfan, Widjajanti I. Suharyo and Satish Mishra (2003). 'Aspiration to Inequality: Regional Disparity and Centre-Regional Conflicts in Indonesia', Paper Presented at the UNU/WIDER Conference on Spatial Inequality in Asia, Tokyo, Japan, 28-29 March.

Tullock, Gordon (1980). 'Efficient Rent Seeking', in JM Buchannan, R D Tollison and G Tullock (eds), Towards a Theory of the Rent-Seeking Society, College Station: Texas A and M University, 97-112.

Tilly, Charles (1978). From Mobilization to Revolution, Reading MA: AddisonWesley.

Zhang, Xiaobo and Ravi Kanbur (2001). 'What Difference Do Polarisation Measures Make? An Application to China', Journal of Development Studies 37(3): 85-98. 